\title{
Sociodemographic and clinical functional factors in pre-frail and frail older adults with type 2 Diabetes Mellitus in relation to low levels of physical activity
}

\author{
Ana Clara Teixeira Fernandes' ${ }^{1}$ \\ Bartolomeu Fagundes de Lima Filho' (ID \\ Íkaro Felipe da Silva Patrício' (ID \\ Vanessa da Nóbrega Dias' (ID \\ Fabrícia Azevêdo da Costa Cavalcantil (ID) \\ Juliana Maria Gazzola?
}

\section{Abstract}

Objective: To determine the sociodemographic and clinical-functional factors related to low levels of physical activity in pre-frail and frail older adults with type 2 diabetes mellitus (DM2). Method: an observational, analytical, cross-sectional study was performed. The sample consisted of older adults aged 60 years or over with a clinical diagnosis of DM2 who were treated at the Onofre Lopes University Hospital (or HUOL). Sociodemographic and clinical-functional data were evaluated with the following instruments: the Timed Up and Go (TUG) test, the Mini Mental State Examination (MMSE), the 15-item Geriatric Depression Scale (GDS), the International Physical Activity Questionnaire (IPAQ) and the frailty phenotype. The Chi-square and Mann Whitney tests were used for data analysis. Results: the study sample consisted of 113 individuals classified as prefrail $(52.2 \%)$ and frail (47.8\%). Low levels of physical activity were verified in $79.6 \%$ of the sample. The most closely related variables that showed a statistically significant difference with low levels of physical activity were: years of schooling $(p=0.02)$, social participation $(p=0.005)$, insulin therapy $(p=0.02)$, pain in the lower limbs $(p=0.03)$ and depressive symptoms $(p=0.04)$. Also, significant differences were found between low levels of physical activity and age $(p=0.04)$ and years of schooling $(p=0.05)$. Conclusions: Low levels of physical activity are associated with certain sociodemographic and clinicalfunctional factors, some of which are modifiable. Identifying these is important for the development of appropriate health interventions for the prevention and treatment of both DM2 and the Frailty Syndrome (FS).

\footnotetext{
Universidade Federal do Rio Grande do Norte, Departamento de Fisioterapia. Natal, RN, Brasil.
}

Funding: Coordination for Higher Education Staff Development (Capes, Coordenação de Aperfeiçoamento de Pessoal de Nível Superior). Number of process:001.

The authors declare there are no conflicts of interest in relation to the present study.

Keywords: Health of the Elderly. Diabetes Mellitus, Type 2. Frailty. 


\section{INTRODUCTION}

Diabetes Mellitus (DM) is a chronic noncommunicable diseases (NCDs), a group of illnesses which represent a significant global cause of morbidity and mortality. In 1990, according to data from the Global Disease Burden Study, NCDs accounted for $43 \%$ of disability adjusted life years (DALY), with this level rising to $54 \%$ in $2010^{1}$.

With population aging, the increased prevalences of obesity, sedentary lifestyles and the urbanization process are considered factors responsible for the global increase in the incidence and prevalence of $\mathrm{DM}^{2}$.

Type 2 Diabetes Mellitus (DM2) is one of the most prevalent NCDs, corresponding to approximately $90 \%$ of all cases of diabetes ${ }^{1}$. It is a metabolic, chronic and non-communicable disease that acts in a deleterious manner, generating blood hyperglycemia and causing damage to organs and systems, especially in the cardiac, visual, renal and nervous systems, which leads to morbidity and increased mortality ${ }^{3}$.

In addition to DM2, Frailty Syndrome (FS) is a notable chronic disease that occurs with the decline in homeostatic reserve capacity and deficits in resistance to stressors ${ }^{3}$. This culminates in susceptibility and the decline of multiple physiological systems ${ }^{4}$, which leads to a reduction in the muscle mass of older adults and a chronic inflammatory state, which, when associated with diseases and other extrinsic factors, leads to a reduction in energy reserves and increased physical vulnerability ${ }^{5}$.

FS is a condition that generates multimorbidities, and is related to sociodemographic factors (the female sex, increased age) and functional clinical factors (reduction of cognitive status, polypharmacy, sarcopenia, falls, among others) ${ }^{6}$. The most common way of measuring its characteristics is based on the frailty phenotype (genetic characteristics associated with interaction with the environment), which describes the main findings about the disease to classify older adults as non-frail, pre-frail and frail ${ }^{7}$.

A pathophysiological mechanism common to FS and DM2, which permeates the limits of effective functionality, is sarcopenia. Muscle decline is the main cause of weakness and slowness, culminating in loss of mobility until falls occur ${ }^{8}$. Sarcopenia forms a FS tripod with neuroendocrine deregulation and immune dysfunction ${ }^{9}$, and may be present in individuals with more advanced diabetes, in which there is an increase in insulin resistance with aging, decreased physical activity, increased visceral fat and, consequently, a reduction of muscle mass ${ }^{10}$.

As the two diseases mentioned above have similar risk factors in several aspects, the treatment of one effects the containment of the other ${ }^{4}$. FS combined with DM2 may result in malnutrition, immobility, balance deficit, dependence in activities of daily living, contractures, deformities, incontinence, hospitalization with an outcome of institutionalization, cognitive deficit and depressive symptoms ${ }^{7}$.

When an individual is diagnosed with FS, they can control their activities and care to improve the symptoms presented. A reduction in the regular practice of physical activity is a potentiating factor of the problems caused by $\mathrm{DM} 2^{10}$ and is considered one of the predictors of the frailty phenotype. Therefore, verifying modifiable related factors associated with these chronic diseases, such as a low level of physical activity (LLPA), may guide therapies that prevent and/or contain their progress among this population.

In addition, there is a scarcity of Brazilian studies that investigate the relationship between DM2 and FS and the specific characteristics of the two diseases. Furthermore, the participants of the present study were outpatients, a fact that allows the control of variables in a more reliable manner, with the manipulation of variables of various categories that care in a high complexity hospital can have.

The aim of the present study was therefore to determine the sociodemographic and clinicalfunctional factors related to LLPA in pre-frail and frail older adults with DM2.

\section{METHOD}

An observational, cross-sectional and analytical study was carried out at the Laboratory of Technological Innovation in Health (or LAIS) of 
the Onofre Lopes University Hospital (or HUOL). The data were collected from February 2016 to February 2018.

The study population consisted of older adults living in the metropolitan region of the city of Natal (Rio Grande do Norte), Brazil, aged 60 years or older with a clinical diagnosis of DM2 according to criteria of the American Diabetes Association (ADA), of both sexes, referred by the Endocrinology and Geriatrics sectors of the HUOL.

The study was approved by the Ethics Committee on Research with Human Beings of the institution and approved under opinion number 1.808.219.

A power of $80 \%$ and a significance level of $5 \%$ were used to perform the sample calculation for the two-tailed hypothesis tests. Of the variables with the greatest statistical significance for the sample (schooling, social participation, insulin use, lower limb pain, depressive symptoms, age), the largest sample size was for "income", with 123 individuals, avoiding possible $\beta$ errors in variables that are close to significance. Therefore, the sample consisted of 125 older adults ( $\mathrm{n}=125)$, based on the sample calculation.

The present study included subjects aged 60 years or older, of both sexes, who could walk freely without an auxiliary device, without amputation of the lower limbs or upper limbs above the level of the metatarsophalangeal and metacarpophalangeal joints, with a clinical diagnosis of DM2 according to the ADA criteria ${ }^{11}$, and who fit the phenotype of frail or pre-frail 7 .

Older adults who could not perform all the tests proposed in the evaluation or who exhibited discomfort that made the tests unfeasible were excluded.

After routine consultations of the older adults in the endocrinology and geriatric outpatient clinics and the clinical diagnosis of DM2, the physician responsible for the consultation advised their patients of the need for an evaluation focusing on this disorder, and invited them to seek evaluation through the Medical and Statistical Archive Service (or SAME) or directly at the LAIS.
This evaluation was performed by a team of six previously trained researchers. Participants were instructed to attend the LAIS on a previously arranged date and time, with the name of the medications used in the week of evaluation and their most recent blood tests. Participants who met the eligibility criteria signed an informed consent form (ICF) after the objectives, protocols and possible risks of the research were explained.

An interview was conducted to obtain the sociodemographic and clinical-functional data. The evaluations lasted about an hour, and included physical and cognitive tests to minimize the tiredness of the participants.

The sociodemographic data were composed of the following variables: sex (female/male), age, age group (60-69 years/ 70 years or more), marital status (married or not married), years of schooling (up to four years (incomplete) and equal to or greater than four years), income (reference values of the salary floor of the northeast region of Brazil updated for 2017, of up to two minimum wages/three or more minimum wages) and social participation (participates/does not participate in community activities).

The clinical-functional factors evaluated were body mass index (BMI), number of associated diseases, number of medications, time since diagnosis of DM2, previous six months' laboratory tests for the control of DM2 (fasting glycemia and glycated hemoglobin), use of insulin, presence of lower limb pain (LL), falls in the previous year. We also used the Timed Up And Go (TUG) test, the Mini Mental State Examination (MMSE), the 15-item Geriatric Depression Scale (GDS) and the International Physical Activity Questionnaire - short version (IPAQ).

The TUG is a practical and quick test that aims to evaluate the mobility and functional balance of older adults. The test consists of the individual getting up from a chair with armrests (46 cm high), walking for three meters, turning around a cone, returning to the chair and their initial position, where the task finishes. The older adult only starts the test following a positive sign from the instructor and is instructed not to talk during the test and to walk at their usual speed. If necessary an auxiliary walking device can be used, however no physical assistance 
is given. The test analyzes the time in seconds that the older adult needs to perform the proposed task. Individuals at a higher risk of falls take longer to perform the test (higher risk of falls - time equal to or greater than 13 seconds) $)^{12,13}$.

The MMSE was used to track cognitive impairment that may cause difficulties for the participants' understanding of commands. This evaluates temporal/spatial orientation, immediate memory, calculation, word recall, naming, repetition, commands, reading, sentence writing, and drawing copies. The median scores based on schooling are: illiterate 20; one-four years of schooling 25; five-eight years of schooling 26.5; nine-eleven years of schooling 28 and over eleven years of schooling $29^{14,15}$.

The GDS-15 was used to track symptoms of depression in participants, and contains 15 different items. A score from zero to four points indicates that the participant does not have depressive symptoms; five to ten points means there are indications of mild or moderate depression; and from eleven to fifteen points, evidence of severe or severe depression. It is important to emphasize that this instrument is not capable of generating a diagnosis of depression ${ }^{16}$.

The IPAQ - short version assesses level of physical activity and contains three questions regarding the weekly frequency and duration in minutes, per day, of physical activity, and the intensity level (vigorous, moderate or walking). It also evaluates the time the individual spends sitting. This questionnaire was validated for the Brazilian population by Matsudo et al. ${ }^{17}$. The IPAQ classified the older adults as follows: very active; active; irregularly active; irregularly active A; irregularly active B; sedentary.

The older adults who were considered as irregularly active or sedentary presented a phenotype of low level of physical activity as positive ${ }^{17}$.

The frailty phenotype was evaluated according to the study by Fried, Tangen and Walston ${ }^{7}$, to classify the elderly as "non-frail", "pre-frail" and "frail". The evaluation criteria are described below: unintentional weight loss ( $\geq 4.5 \mathrm{~kg}$ or $\geq 5 \%$ of weight in the previous year); decrease in grip strength using the SH5002 Smedley-Saehaen Manual Dynamometer (dominant hand), with cut-off points adjusted for sex and BMI; exhaustion through self-reporting of fatigue, measured by two questions from the Center for Epidemiological Studies (CES-D), described by Batistoni, Neri and Cupertino ${ }^{18}$ : "I felt that I had to make an effort to do my usual tasks" and "I could not carry out my activities". Older adults who obtained a score of three or four in any of the questions met the criterion.

LLPA was measured by the short version of the International Physical Activity Questionnaire (IPAQ); and a decrease in gait speed calculated through the time in seconds needed to travel 4.6 meters, adjusted for sex and height.

With the phenotype, the older adults are considered frail if they present three or more positive criteria, pre-frail if they present one or two positive criteria and non-frail if they present no positive criteria ${ }^{7}$.

Analysis of the normality of data distribution was performed by the Kolmogorov-Smirnov test, and nonparametric distribution was found.

Descriptive analysis of the data was performed. The inferential analysis was carried out through associations between the dependent qualitative variable (level of physical activity) and the independent dichotomous variables using the Chi-square test. The association between the level of physical activity with the quantitative variables was performed by the Mann-Whitney test. A significance level of 5\% was adopted.

\section{RESULTS}

A total of 125 individuals were evaluated, of whom 12 were excluded for not having the frailty phenotype. The study had a sample of 113 subjects, of whom $59(52,2 \%)$ were characterized as pre-frail and $54(47.8 \%)$ as frail, and 90 of whom had LLPA. The mean age of the sample was 68.6 ( \pm 6.62 years); the predominant sex was female $(61.9 \%)$; the mean schooling was 6.65 years ( \pm 5.11 years of schooling) and the average income of the sample was $\mathrm{R} \$ 2,367.74$ reais/month. A total of $79.6 \%(n=90)$ of the total population had LLPA. 
Table 1 presents the sociodemographic and clinical-functional characterization of the sample. Most of the participants were sedentary women $(63.3 \%)$, with a low level of schooling $(65.6 \%)$, who were overweight $(60.0 \%)$, had five or more associated diseases $(58.9 \%)$, used five or more medications $(58.9 \%)$, did not use insulin $(75,6 \%)$, felt pain in lower limbs (58.9\%) and had depressive symptoms (62.2\%).

Table 2 shows the relationship between LLPA and sociodemographic and clinical-functional variables. The results showed that LLPA is present in older adults with low levels of schooling, who do not participate in community activities, do not use insulin, have lower limb pain and depressive symptoms.

Table 3 shows the values found in the relationship between LLPA and the quantitative sociodemographic and clinical-functional variables (Mann-Whitney test). The results show that age and years of schooling are related to LLPA.

Table 1. Sociodemographic and clinical-functional characterization of the sample of pre-frail and frail older adults with type 2 Diabetes Mellitus, according to Low Level of Physical Activity ( $\mathrm{n}=113$ ). Natal, Rio Grande do Norte, 2019.

\begin{tabular}{|c|c|c|}
\hline \multirow[b]{2}{*}{ Variables } & \multicolumn{2}{|c|}{ Low level of physical activity } \\
\hline & $\begin{array}{l}\text { Yes } \\
\mathrm{n}=90(79.6 \%)\end{array}$ & $\begin{array}{l}\text { No } \\
\mathrm{n}=23(20.4 \%)\end{array}$ \\
\hline \multicolumn{3}{|l|}{$\operatorname{Sex}(n=113)$} \\
\hline Female & $57(63.3 \%)$ & $13(56.5 \%)$ \\
\hline Male & $33(36.7 \%)$ & $10(43.5 \%)$ \\
\hline \multicolumn{3}{|l|}{ Age group $(n=113)$} \\
\hline $60-69$ years & $51(61.1 \%)$ & $16(69.9 \%)$ \\
\hline 70 years or more & $35(38.9 \%)$ & $07(30.4 \%)$ \\
\hline \multicolumn{3}{|l|}{ Marital status ( $\mathrm{n}=113$ ) } \\
\hline Married & $56(62.2 \%)$ & $18(78.3 \%)$ \\
\hline Not married & $34(37.8 \%)$ & $05(21.7 \%)$ \\
\hline \multicolumn{3}{|l|}{ Years of schooling $(\mathrm{n}=113)$} \\
\hline Up to 4 years (incomplete) & $59(65.6 \%)$ & $09(39.1 \%)$ \\
\hline 4 years or more & $31(34.4 \%)$ & $14(60.9 \%)$ \\
\hline \multicolumn{3}{|l|}{ Income } \\
\hline Up to 2 minimum wages & $53(58.9 \%)$ & $09(39.1 \%)$ \\
\hline 3 or more minimum wages & $37(41.1 \%)$ & $14(60.9 \%)$ \\
\hline \multicolumn{3}{|l|}{ Social participation } \\
\hline Participates in community activities & $45(50.0 \%)$ & $19(82.6 \%)$ \\
\hline Does not participate in community activities & $45(50.0 \%)$ & $04(17.4 \%)$ \\
\hline \multicolumn{3}{|l|}{ Body mass index } \\
\hline Undernourished or normal weight & $36(40.0 \%)$ & $08(34.8 \%)$ \\
\hline Overweight & $54(60.0 \%)$ & $15(65.2 \%)$ \\
\hline \multicolumn{3}{|l|}{ Number of diseases } \\
\hline 1 to 4 & $33(36.7 \%)$ & $06(26.1 \%)$ \\
\hline 5 or more & $57(63.3 \%)$ & $17(73.9 \%)$ \\
\hline \multicolumn{3}{|l|}{ Number of medicines $(\mathrm{n}=110)$} \\
\hline 1 to 4 & $35(38.9 \%)$ & $07(31.8 \%)$ \\
\hline 5 or more & $53(58.9 \%)$ & $15(68.2 \%)$ \\
\hline
\end{tabular}


Continuation of Table 1

\begin{tabular}{|c|c|c|}
\hline \multirow[b]{2}{*}{ Variables } & \multicolumn{2}{|c|}{ Low level of physical activity } \\
\hline & $\begin{array}{l}\text { Yes } \\
\mathrm{n}=90(79.6 \%)\end{array}$ & $\begin{array}{l}\text { No } \\
\mathrm{n}=23(20.4 \%)\end{array}$ \\
\hline \multicolumn{3}{|l|}{ Time since diagnosis $(\mathrm{n}=108)$} \\
\hline 0 to 5 years & $36(41.9 \%)$ & $05(22.7 \%)$ \\
\hline 6 or more years & $50(55.6 \%)$ & $17(77.3 \%)$ \\
\hline \multicolumn{3}{|l|}{ Glycated hemoglobin $(\mathrm{n}=82)$} \\
\hline Normal (up to $8 \%$ ) & $33(50.0 \%)$ & $11(68.8 \%)$ \\
\hline Alter $(8.1 \%$ or more $)$ & $33(50.0 \%)$ & $05(31.3 \%)$ \\
\hline \multicolumn{3}{|l|}{ Fasting glycemia $(\mathrm{n}=108)$} \\
\hline Normal (0-130mg/dL) & $43(50.0 \%)$ & $12(54.5 \%)$ \\
\hline Altered (131 mg/dL or more) & $43(50.0 \%)$ & $10(45.5 \%)$ \\
\hline \multicolumn{3}{|l|}{ Insulin use } \\
\hline Yes & $22(24.4 \%)$ & $11(47.8 \%)$ \\
\hline No & $68(75.6 \%)$ & $12(52.2 \%)$ \\
\hline \multicolumn{3}{|l|}{ Pain in lower limbs $(n=113)$} \\
\hline Yes & $53(58.9 \%)$ & $08(34.8 \%)$ \\
\hline No & $37(41.1 \%)$ & $15(65.2 \%)$ \\
\hline \multicolumn{3}{|l|}{ Falls in the last year $(n=113)$} \\
\hline Yes & $33(36.7 \%)$ & $08(34.8 \%)$ \\
\hline No & $57(63.3 \%)$ & $15(65.2 \%)$ \\
\hline \multicolumn{3}{|l|}{ Mini Mental State Examination $(n=113)$} \\
\hline Presents cognitive deficit & $35(38.9 \%)$ & $11(47.8 \%)$ \\
\hline Does not present cognitive deficit & $55(61.1 \%)$ & $12(52.2 \%)$ \\
\hline \multicolumn{3}{|l|}{ Depressive symptoms ( $\mathrm{n}=113$ ) } \\
\hline Presents depressive symptoms & $56(62.2 \%)$ & $09(39.1 \%)$ \\
\hline Does not have depressive symptoms & $34(37.8 \%)$ & $14(60.9 \%)$ \\
\hline \multicolumn{3}{|l|}{ Risk of falls $(\mathrm{n}=106)$} \\
\hline Lower risk of falls & $67(78.8 \%)$ & $19(90.5 \%)$ \\
\hline Increased risk of falls & $18(21.2 \%)$ & $02(09.5 \%)$ \\
\hline
\end{tabular}

Source: Study data, 2019.

Table 2. Analysis of low level of physical activity with sociodemographic and clinical-functional variables categorical dichotomous of the sample of older adults with Type 2 Diabetes Mellitus. Natal, Rio Grande do Norte, 2019.

\begin{tabular}{lllll}
\hline \multirow{2}{*}{ Variables } & \multicolumn{2}{l}{ Low level of physical activity } & & \\
& Yes & No & P-value & OR (CI: 95\%) \\
\hline Sex & $\mathrm{n}(\%)$ & $\mathrm{n}(\%)$ & 0.54 & $0.75(0.29-1.90)$ \\
Female & $57(50.4 \%)$ & $13(11.5 \%)$ & & \\
Male & $33(29.2 \%)$ & $10(8.8 \%)$ & & $0.68(0.25-1.83)$ \\
Age group (in years) & & & \\
$60-69$ & $55(48.7 \%)$ & $16(14.2 \%)$ & 0.45 & \\
70 or more & $35(31.0 \%)$ & $07(6.2 \%)$ & & \\
\hline
\end{tabular}


Continuation of Table 2

\begin{tabular}{|c|c|c|c|c|}
\hline \multirow{3}{*}{ Variables } & \multicolumn{4}{|c|}{ Low level of physical activity } \\
\hline & Yes & No & & \\
\hline & $\mathrm{n}(\%)$ & $\mathrm{n}(\%)$ & $p$-value & OR (CI: 95\%) \\
\hline \multicolumn{5}{|l|}{ Marital status } \\
\hline Not married & $34(30.1 \%)$ & $05(4.4 \%)$ & 0.14 & $2.18(0.74-6.42)$ \\
\hline Married & $56(49.6 \%)$ & $18(15.9 \%)$ & & \\
\hline \multicolumn{5}{|l|}{ Years of schooling } \\
\hline Up to 4 (incomplete) & $59(52.2 \%)$ & $09(8.0 \%)$ & $0.02 *$ & $2.96(1.15-7.60)$ \\
\hline 4 years or older & $31(27.4 \%)$ & $14(12.4 \%)$ & & \\
\hline \multicolumn{5}{|l|}{ Income (minimum wages) } \\
\hline $0-2$ & $53(43.9 \%)$ & $09(8.0 \%)$ & 0.08 & $2.22(0.87-5.68)$ \\
\hline 3 or more & $37(32.7 \%)$ & $14(12.4 \%)$ & & \\
\hline \multicolumn{5}{|l|}{ Social participation } \\
\hline Participates in community activities & $45(39.8 \%)$ & $19(16.8 \%)$ & $0.005^{*}$ & $0.21(0.06-0.66)$ \\
\hline Does not participate in community activities & $45(39.8 \%)$ & $04(3.5 \%)$ & & \\
\hline \multicolumn{5}{|l|}{ Body mass index } \\
\hline Undernourished or normal weight & $36(31.9 \%)$ & $08(7.1 \%)$ & 0.64 & $1.25(0.48-3.25)$ \\
\hline Overweight & $54(47.8 \%)$ & $15(13.3 \%)$ & & \\
\hline \multicolumn{5}{|l|}{ Number of diseases } \\
\hline 1 to 4 & $33(29.2 \%)$ & $06(5.3 \%)$ & 0.34 & $1.64(0.58-4.57)$ \\
\hline 5 or more & $57(50.4 \%)$ & $17(15.0 \%)$ & & \\
\hline \multicolumn{5}{|l|}{ Number of medicines } \\
\hline 1 to 4 & $35(31.8 \%)$ & $07(6.4 \%)$ & 0.49 & $1.41(0.52-3.82)$ \\
\hline 5 or more & $53(48.2 \%)$ & $15(13.6 \%)$ & & \\
\hline \multicolumn{5}{|l|}{ Time since diagnosis } \\
\hline 0 to 5 years & $36(33.3 \%)$ & $05(4.6 \%)$ & 0.09 & $2.44(0.82-7.24)$ \\
\hline 6 or more years & $50(46.3 \%$ & $17(15.7 \%)$ & & \\
\hline \multicolumn{5}{|l|}{ Glycated hemoglobin } \\
\hline Normal (up to $8 \%$ ) & $33(40.2 \%)$ & $11(13.4 \%)$ & 0.17 & $0.45(0.14-1.45)$ \\
\hline Altered $(8.1 \%$ or more $)$ & $33(40.2 \%)$ & $05(6.1 \%)$ & & \\
\hline \multicolumn{5}{|l|}{ Fasting glycemia } \\
\hline Normal (0-130mg/dL) & $43(39.8 \%)$ & $12(11.1 \%)$ & 0.70 & $0.83(0.32-2.13)$ \\
\hline Altered (131 mg/dL or more) & $43(39.8 \%)$ & $10(9.3 \%)$ & & \\
\hline \multicolumn{5}{|l|}{ Insulin use } \\
\hline Yes & $22(19.5 \%)$ & $11(9.7 \%)$ & $0.02 *$ & $0.35(0.13-0.91)$ \\
\hline No & $68\left(60.2^{\%} \%\right)$ & $12(10.6 \%)$ & & \\
\hline \multicolumn{5}{|l|}{ Pain in lower limbs } \\
\hline Yes & $53(46.9 \%)$ & $08(7.1 \%)$ & $0.03 *$ & $2.68(1.03-6.98)$ \\
\hline No & $37(32.7 \%)$ & $15(13.3 \%)$ & & \\
\hline \multicolumn{5}{|l|}{ Falls in recent years } \\
\hline Yes & $33(29.2 \%)$ & $08(7.1 \%)$ & 0.86 & $0.92(0.35-2.40)$ \\
\hline No & $57(50.4 \%)$ & $15(13.3 \%)$ & & \\
\hline
\end{tabular}


Continuation of Table 2

\begin{tabular}{lllll}
\hline & \multicolumn{2}{l}{ Low level of physical activity } & & \\
Variables & Yes & No & O-value & OR (CI: $95 \%)$ \\
\hline Mini Mental State Examination & $\mathrm{n}(\%)$ & $\mathrm{n}(\%)$ & \\
Presents cognitive deficit & $35(31.0 \%)$ & $11(9.7 \%)$ & 0.43 & $0.69(0.27-1.74)$ \\
Does not present cognitive deficit & $55(48.7 \%)$ & $12(10.6 \%)$ & & $2.56(1.00-6.55)$ \\
Depressive symptoms & & & \\
Presents depressive symptoms & $56(49.6 \%)$ & $09(8.0 \%)$ & $\mathbf{0 . 0 4 *}$ & \\
Does not have depressive symptoms & $34(30.1 \%)$ & $14(12.4 \%)$ & & $0.39(0.08-1.84)$ \\
\hline Risk of falls & & & \\
Lower risk of falls & $67(63.2 \%)$ & $19(17.9 \%)$ & 0.22 & \\
Increased risk of falls & $18(17.0 \%)$ & $2(1.9 \%)$ & & \\
\hline
\end{tabular}

*statistically significant values $(p \leq 0.05)$.

Source: Study data, 2019.

Table 3. Relationship between low level of physical activity and quantitative sociodemographic and clinicalfunctional variables of a sample of older adults with type 2 Diabetes Mellitus. Natal, Rio Grande do Norte, 2019.

\begin{tabular}{|c|c|c|c|c|c|}
\hline Variables & $\begin{array}{l}\text { Low level of } \\
\text { physical activity }\end{array}$ & $\mathrm{N}$ & Median ( $( \pm s d)$ & Variation & $p$-value \\
\hline \multirow[t]{2}{*}{ Age } & Yes & 90 & $68(6.62)$ & $60-86$ & 0.04 \\
\hline & No & 23 & & & \\
\hline \multirow[t]{2}{*}{ Years of schooling } & Yes & 90 & $6(5.11)$ & $0-21$ & 0.05 \\
\hline & No & 23 & & & \\
\hline \multirow[t]{2}{*}{ Income } & Yes & 90 & $1874(1385.90)$ & $700-7000$ & 0.36 \\
\hline & No & 23 & & & \\
\hline \multirow[t]{2}{*}{ Body mass index } & Yes & 90 & $28.4(4.45)$ & $16.8-41.6$ & 0.53 \\
\hline & No & 23 & & & \\
\hline \multirow[t]{2}{*}{ Number of medicines } & Yes & 90 & $5(2.94)$ & $0-14$ & 0.70 \\
\hline & No & 23 & & & \\
\hline \multirow[t]{2}{*}{ Time since diagnosis } & Yes & 86 & $10(10.67)$ & $1-50$ & 0.45 \\
\hline & No & 22 & & & \\
\hline \multirow[t]{2}{*}{ Glycated hemoglobin } & Yes & 66 & $7.6(10.69)$ & $5.0-10.6$ & 0.38 \\
\hline & No & 16 & & & \\
\hline \multirow[t]{2}{*}{ Fasting glycemia } & Yes & 86 & $129(76.39)$ & $66-532$ & 0.29 \\
\hline & No & 22 & & & \\
\hline \multirow[t]{2}{*}{ Mini Mental State Examination } & Yes & 90 & $25(4.22)$ & $14-30$ & 0.68 \\
\hline & No & 23 & & & \\
\hline \multirow[t]{2}{*}{ Geriatric Depression Scale of 15 items } & Yes & 90 & $5(2.92)$ & $0-14$ & 0.10 \\
\hline & No & 23 & & & \\
\hline \multirow[t]{2}{*}{ Timed Up And Go Test } & Yes & 85 & $10.06(9.67)$ & $6.11-29.0$ & 0.45 \\
\hline & No & 22 & & & \\
\hline
\end{tabular}

Source: Study data, 2019. 


\section{DISCUSSION}

In the present study, it was identified that $47.8 \%$ of the sample was considered frail and $79.6 \%$ had LLPA. LLPA contributes to an increased risk of being frail and older adults considered frail suffer a decline in muscle strength, reduced gait speed and low tolerance to exercise ${ }^{3}$. This confirms the importance of emphasizing the adoption of healthy life habits among this population ${ }^{19}$, such as the regular practice of physical exercise, especially resistance training (RT), which is essential for the maintenance, gain or reduction of loss of muscle mass and strength, mobility and functional capacity of older adults ${ }^{20}$. A healthy lifestyle can help control and protect against NCDs and it is essential that health professionals provide guidance at both primary and secondary levels of health care through strategies such as health education groups and interventions that can introduce physical exercise into the daily life of this population ${ }^{21}$.

A total of $63.6 \%$ of the sample with LLPA were women. It has been observed that women seek health services more frequently and this fact may have influenced such predominance, as the sample is from a specialized health unit. In a study that verified the difficulties and motivations involved in physical exercise among older women, it was found that women in this age group have a poor perception of their health status and perceive that they have limitations, so there is a greater distrust of performing physical exercise. In addition, they consider themselves "caregivers" of the family, so self-care is not a priority ${ }^{22}$. On the other hand, if educational actions are carried out that can explain the health and disease process, and how physical exercise can bring benefits by reducing these limitations, stimulating socialization, and improving and/or maintaining autonomy, there is a change in perception $^{22}$.

Regarding the years of schooling of the sample, there was statistical significance between years of schooling and a LLPA ( $p=0.02$ ). In addition, $52.2 \%$ of the sample had up to four years of schooling. This low level of education was considered a risk factor for the development of LLPA. The data on schooling found in the present study are equivalent to that of older Brazilians. These findings reinforce that the lower the education of the older adult, the lower their adherence to physical activity, which may contribute to a worsening of health conditions ${ }^{23}$.

It is up to health professionals to guide older adults on the importance of regular physical activity, as this is paramount for maintaining their functional capacity. It is related to a better perception of quality of life, since the functional limitations of elderly people interfere in their autonomy for performing activities of daily living ${ }^{24}$.

In a study conducted in Brazil with data from the National Health Survey (2013), it was observed that illiterate older adults tend to have poor selfperception of their health. In addition, schooling acts as a protective factor in relation to the health of the individual, with regard to obtaining knowledge and access to information, which also leads to the understanding of one's own health and disease process $^{25}$.

Furthermore, the association found between social participation and LLPA was statistically significant $(p=0.005)$ and the former was considered a protective factor for LLPA. Social behavior is modified as people age and is influenced by personal aspects such as health, sex, education and income. Studies have identified a reduction in social participation associated with age ${ }^{26}$. Based on this premise, influencing older adults to adhere to social activities such as participation in clubs, sports academies, charitable organizations or church reduces the chance of a sedentary lifestyle ${ }^{27}$.

In addition, $70.8 \%$ of the sample reported not using insulin, that is, it is likely there was no lack of control of glycemic levels. The non-use of insulin was considered a positive factor for physical activity.

Studies have found that DM2 causes neuromuscular deterioration and aerobic and resistance training are used as non-pharmacological treatments that lead to the adaptation of skeletal muscle, avoiding functional limitations in this population ${ }^{28}$, as well as reducing the chance of using insulin as a form of treatment of DM2 in older adults ${ }^{29}$. 
The prevalence of lower limb pain complaints was $46.9 \%$ in older adults who had LLPA, and this characteristic behaved as a risk factor for physical activity. Pain is related to the biological and psychosocial changes associated with aging, intrinsic and inherent to the individual themselves and may favor or be possible risk factors for the occurrence of falls ${ }^{30}$.

Moreover, depressive symptoms were prevalent in more than half the sample (57.6\%). Having depressive symptoms is considered a risk factor for LLPA, in addition to worsening the symptoms of chronic diseases. One study verified the relationship between depressive symptoms and levels of physical activity and found that older adults with chronic diseases, such as DM2, have worse rates of physical activity and sleep quality ${ }^{31}$. In addition, individuals with depression tend to adopt behaviors that are harmful to their health, such as a sedentary lifestyle ${ }^{32}$.

The most prevalent age range in the present study was 60-69 years, totaling $71(62.9 \%)$ individuals, with a mean age of $68( \pm 6.62)$ years of age. There was statistical significance between age and LLPA ( $p=0.04$ ), with the older the age, the lower the level of physical activity in the sample studied. The fraction of individuals who do not reach minimum levels of physical activity is greater in older Brazilians aged 60 years or older, women and the socioeconomically vulnerable ${ }^{33}$. It should be noted that LLPA can lead to a loss of functional mobility, strength and muscle endurance, and this problem worsens over the years, leading to a loss of autonomy, quality of life and the occurrence of falls, the incidence of which increases after the sixth decade of life ${ }^{34}$.

Falls are considered one of the main causes of injuries and deaths in older people and acting on modifiable risk factors is relevant. This is a great concern for public health, as the costs to the Brazilian National Health Service for the treatment of fractures resulting from falls is more than $\mathrm{R} \$ 51$ million each year ${ }^{35}$.

In this sense, although individuals with NCD perform less physical activity, a study that verified the prevalence of physical activity with the IPAQ among older Brazilian adults (50 or more) found that there was no association between NCDs and LLPA, a fact that suggests that age and schooling may be determinant for this behavior. Even if there is no such association, identifying factors that lead to LLPA is important, as it can prevent NCDs, functional limitations and mortality ${ }^{33}$.

Due to the above-mentioned findings, the results of the present study can provide information about older adults at risk of disability and help identify reversible risk factors. It is important that longitudinal studies that more accurately assess the impact of DM2 on the older population are performed, specifically those that assess the influence of this disorder on the level of physical activity of such individuals, as these factors can lead to frailty, in an attempt to improve and/or preserve the quality of life of this population.

Among the limitations of this research are its cross-sectional design, which does not allow a cause and effect association to be established, and the lack of Brazilian studies into DM2 and the FS and their associated factors. Difficulty was also experienced when obtaining the values of glycated hemoglobin and fasting glycemia of the older participants, who occasionally did not have the recent values of these variables, which led to a reduction in cases of DM.

\section{CONCLUSION}

From the results of the present study it can be concluded that the low level of physical activity in pre-frail and frail older adults with type 2 Diabetes Mellitus is associated with low schooling, nonparticipation in social activities, lower limb pain, the presence of depressive symptoms and age. Some of these factors are modifiable, and identifying them is relevant for the development of adequate health interventions and the development of public health policies for the prevention and treatment of both type 2 diabetes mellitus and the frailty syndrome.

Edited by: Ana Carolina Lima Cavaletti 


\section{REFERENCES}

1. Costa AF, Flor LS, Campos MR, Oliveira AF, Costa MFS, Silva RS, et al. Burden of type 2 diabetes mellitus in Brazil. Cad Saúde Pública [Internet]. 2017 [acesso em 01 maio 2019];33(2):e00197915 [14 p.]. Disponível em: http://www.scielo.br/pdf/csp/ v33n2/1678-4464-csp-33-02-e00197915.pdf

2. Flor LS, Campos MR. The prevalence of diabetes mellitus and its associated factors in the Brazilian adult population: evidence from a population-based survey. Rev Bras Epidemiol [Internet]. 2017 [acesso em 28 fev. 2020];20(1):16-29. Disponível em: http:// www.scielo.br/pdf/rbepid/v20n1/en_1980-5497rbepid-20-01-00016.pdf

3. Lima LR, Funghetto SS, Volpe CRG, Santos WS, Funez MI, Stival MM. Quality of life and time since diagnosis of diabetes mellitus among the elderly. Rev Bras Geriatr Gerontol [Internet]. 2018 [acesso em 28 fev. 2020];21(2):180-90. Disponível em: http://www.scielo.br/pdf/rbgg/v21n2/1809-9823rbgg-21-02-00176.pdf

4. Silva AP, Pureza DY, Landre BC. Frailty syndrome in elderly patients with type 2 diabetes mellitus. Acta Paul Enferm [Internet]. 2015 [acesso em 01 maio 2019];28(6):503-9. Disponível em: http://www.scielo. br/pdf/ape/v28n6/1982-0194-ape-28-06-0503.pdf

5. Andrade JM, Duarte YAO, Alves LC, Andrade FCD, Souza Junior PRB, Lima-Costa MF, et al. Frailty profile in Brazilian older adults: ELSI-Brazil. Rev Saúde Pública [Internet]. 2018 [acesso em 28 fev. 2020];52 Supl 2:1-10. Disponível em: http://www. scielo.br/pdf/rsp/v52s2/pt_0034-8910-rsp-52s2-S1518-87872018052000616.pdf

6. Fhon JRS, Rodrigues RAP, Santos JLF, Diniz MA, Santos EB, Almeida VC, et al. Fatores associados à fragilidade em idosos: estudo longitudinal. Rev Saúde Pública [Internet]. 2018 [acesso em 01 jun. 2019];52:18. Disponível em: http://www.scielo.br/pdf/rsp/v52/ pt_0034-8910-rsp-S1518-52-87872018052000497.pdf

7. Fried LP, Tagen CM, Walston J, Newman AB, Hirsch NC, Gottdiene J, et al. Frailty in older adults: evidence for a phenotype. J Gerontol Ser A Biol Med Sci [Internet]. 2001 [acesso em 01 maio 2019];56(3):146-56. Disponível em: https://www.ncbi. nlm.nih.gov/pubmed/11253156

8. Morley JE, Vellas B, Kan GAV, Anker SD, Bauer JM, Bernabei R, et al. Frailty consensus: a call to action. J Am Med Dir Assoc [Internet]. 2013 [acesso em 01 maio 2019];14(6):392-7. Disponível em: https://www. ncbi.nlm.nih.gov/pmc/articles/PMC4084863/pdf/ nihms589815.pdf
9. Freitas EV. Diabetes Melito. In: Freitas EV, Py L. Tratado de geriatria e gerontologia. $3^{\mathrm{a}} \mathrm{ed}$. Rio de Janeiro: Guanabra Koogan; 2013. Capítulo 70.

10. Sociedade Brasileira de Diabetes. Diretrizes da Sociedade Brasileira de Diabetes (2017-2018). São Paulo: Clannad; 2017 [acesso em 01 maio 2019]. Disponível em: https://www.diabetes.org.br/ profissionais/images/2017/diretrizes/diretrizessbd-2017-2018.pdf

11. American Diabetes Association. Diagnosis and Classification of Diabetes Mellitus Diabetes Care [Internet]. 2010 [acesso em 01 maio 2019];33(1):5629. Disponível em: https://care.diabetesjournals.org/ content/33/Supplement_1/S62.full

12. Aveiro MC, Driusso P, Barham EJ, Pavarini SCI, Oishi J. Mobility and the risk of falls among elderly people of the community of São Carlos. Ciênc Saúde Colet [Internet]. 2012 [acesso em 01 maio 2019];17(9):2481-8. Disponível em: http://www.scielo. br/pdf/csc/v17n9/a28v17n9.pdf

13. Podsiadlo D, Richardson S. The Timed "Up \& Go": a test of basical functional mobility for frail elderly persons. J Am Geriatr Soc [Internet]. 1991 [acesso em 01 maio 2019];39(2):142-8. Disponível em: https:// onlinelibrary.wiley.com/resolve/openurl?genre $=$ articl e\&sid $=$ nlm:pubmed\&issn $=0002-8614 \&$ date $=1991 \& \mathrm{v}$ olume $=39 \&$ issue $=2 \&$ spage $=142$

14. Brucki SMD, Nitrini R, Caramelli P, Bertolucci PHF, Okamoto IH. Suggestions for utilization of the mini-mental state examination in Brazil. Arq Neuropsiquiatr [Internet]. 2003 [acesso em 01 maio 2019];61(3):777-81. Disponível em: http://www.scielo. br/pdf/anp/v61n3B/17294.pdf

15. Almeida OP. The Mini-Mental State Examination and the Diagnosis of Dementia in Brazil. Arq Neuropsiquiatr [Internet]. 1998 [acesso em 01 maio 2019];56(3):1-10. Disponível em: http://www.scielo. br/scielo.php?script $=$ sci_arttext\&pid=S0004282X1998000400014

16. Batistoni SST, Neri AL, Cupertino APFB. Validity of the Center for Epidemiological Studies Depression Scale among Brazilian elderly. Rev Saúde Pública [Internet]. 2007 [acesso em 05 maio 2019];41(4):598605. Disponível em: http://www.scielo.br/pdf/rsp/ v41n4/5833.pdf

17. Matsudo S, Araújo T, Matsudo V, Andrade D, Andrade E, Oliveira LC, et al. International Physical Activity Questionnaire (IPAQ): Study of validity and reliability in Brazil. Rev Bras Ativ Fis Saúde. 2001[acesso em 05 maio 2019];6(2):5-18. Disponível em: http://rbafs.org.br/RBAFS/article/view/931/1222 
18. Batistoni SST, Neri AL, Cupertino APFB. Validity of the center for epidemiological studies depression scale among Brazilian elderly. Rev. Saúde Pública [Internet]. 2007 [acesso em 02 maio 2019];41(4):598-605. Disponível em: http://www. scielo.br/scielo.php?script $=$ sci_arttext\&pid=S003489102007000400014\&lng=pt\&nrm=iso\&tlng=en

19. Tavares RE, Jesus MCP, Machado DR, Braga VAS, Tocantins FR, Merighi MAB. Healthy aging from the perspective of the elderly: an integrative review. Rev Bras Geriatr Gerontol [Internet]. 2017 [acesso em 18 fev. 2020];20(6):889-900. Disponível em: http://www.scielo.br/pdf/rbgg/v20n6/1809-9823rbgg-20-06-00878.pdf

20. Allendorf DB, Schopf PP, Gonçalves BC, Closs VE, Gottlieb MGV. Elderly resistance training practitioners have better mobility than physically active elderly non-practitioners. Rev Bras Cienc Mov [Internet]. 2016 [acesso em 11 mar. 2020];24(1):13444. Disponível em: http://docs.bvsalud.org/ biblioref/2017/10/859734/idosos-praticantes-detreinamento-resistido.pdf

21. Bernini LS, Barrile SR, Mangili AF, Arca EA, Correr $\mathrm{R}$, Ximenes MA, et al. O The impact of diabetes mellitus on the quality of life of patients of Primary Health Care. Cad Bras Ter Ocup [Internet]. 2017 [acesso em 18 fev. 2020];25(3):533-41. Disponível em: http://www.cadernosdeterapiaocupacional.ufscar.br/ index.php/cadernos/article/download/1531/880

22. Benavente YL, Sánchez JÁ, Sánchez TR, Cerezuela MBL, Noguera AS, Abellán MDM. Difficulties and motivations for physical exerise in women older than 65 years: A qualitative study. Rev Latinoam Enferm [Internet]. 2018 [acesso em 11 mar. 2020];26:2989. Disponível em: http://www.scielo.br/pdf/rlae/ v26/0104-1169-rlae-26-e2989.pdf

23. Smith BE, Hendrick P, Smith TO, Bateman M, Moffatt F, Rathleff MS. Should exercises be painful in the management of chronic musculoskeletal pain?: a systematic review and meta-analysis. $\mathrm{Br}$ J Sports Med [Internet]. 2017 [acesso em 02 jun. 2020];51(23):1679-87. Disponível em: https://bjsm. bmj.com/content/51/23/1679.long

24. Ferreira LK, Meireles JFF, Ferreira MEC. Evaluation of lifestyle and quality of life in the elderly: a literature review. Rev Bras Geriatr Gerontol [Internet]. 2018 [acesso em 18 fev. 2020];21(5):639-51. Disponível em: http://www.scielo.br/pdf/rbgg/v21n5/pt_1809-9823rbgg-21-05-00616.pdf
25. Zanesco C, Bordin D, Santos SB, Müller EV, Fadel $\mathrm{CB}$. Factors determining the negative perception of the health of Brazilian elderly people. Rev Bras Geriatr Gerontol [Internet]. 2018 [acesso em 18 fev. 2020];21(3):293-303. Disponível em: http:// www.scielo.br/pdf/rbgg/v21n3/pt_1809-9823rbgg-21-03-00283.pdf

26. Pinto JM, Neri AL. Trajectories of social participation in old age: a systematic literature review. Rev Bras Geriatr Gerontol [Internet]. 2017 [acesso em 28 fev. 2020];20(2):260-73. Disponível em: http:// www.scielo.br/pdf/rbgg/v20n2/pt_1809-9823rbgg-20-02-00259.pdf

27. Shaw RJ, Čukić I, Deary IJ, Gale CR, Chastin SFM, Dall PM, et al. The influence of Neighbourhoods and the Social Environment on Sedentary Behaviour in Older Adults in Three Prospective Cohorts. Int J Environ Res Public Health [Internet]. 2017 [acesso em 01 jun. 2019];14(6):1-23. Disponível em: https:// www.mdpi.com/1660-4601/14/6/557

28. Zanuso S, Sacchetti M, Sundberg CJ, Orlando G, Benvenuti P, Balducci S. Exercise in type 2 diabetes: genetic, metabolic and neuromuscular adaptations: a review of the evidence. Br J Sports Med [Internet]. 2017 [acesso em 01 jun. 2019];51(21):153338. Disponível em: http://bjsm.bmj.com/cgi/ pmidlookup? view $=$ long\&pmid $=28501806$.

29. Ely KZ, Spode FS, Barcella RC, Schonhofen IV, Paiva D, Pohl HH, et al. Physical exercise in Diabetes Mellitus, a narrative review. Cinergis [Internet] 2017 [acesso em 28 fev. 2020];18(Supl 1):381-5. Disponível em: https://online.unisc.br/seer/index. php/cinergis/article/view/11175

30. Smith BE, Hendrick P, Smith TO, Bateman M, Moffatt F, Rathleff MS. Should exercises be painful in the management of chronic musculoskeletal pain?: a systematic review and meta-analysis. Br J Sports Med. 2017 [acesso em 02 jun. 2019];51(23):167987. Disponível em: https://bjsm.bmj.com/ content/51/23/1679.long

31. Silva MR, Ferretti F, Pinto SS, Tombini Filho OF. Sintomas depressivos em idosos e sua relação com dor crônica, doenças crônicas, qualidade do sono e nível de atividade física. Br J Pain [Internet]. 2018 [acesso em 02 jun. 2019];1(4):293-8. Disponível em: http://www.scielo.br/pdf/brjp/v1n4/pt_1806-0013brjp-01-04-0293.pdf 
32. Barros MBA, Lima MG, Azevedo RCS, Medina LBP, Lopes CS, Menezes PR, et al. Depression and health behaviors in Brazilian adults - PNS 2013. Rev Saúde Pública [Internet]. 2017 [acesso em 18 fev. 2020];51 Suppl 1: 1-8. Disponível em: http://www.scielo.br/pdf/rsp/v51s1/0034-8910rsp-S1518-87872017051000084.pdf

33. Peixoto SV, Mambrini JVM, Firmo JOA, de Loyola Filho AI, de Souza Junior PRBS, Andrade FB, et al. Prática de atividade física entre adultos mais velhos: resultados do ELSI-Brasil. Rev Saúde Pública. 2018 [acesso em 03 jun. 2019];52 Supl 2:1-9. Disponível em: http://www.scielo.br/pdf/rsp/v52s2/pt_0034-8910rsp-52-s2-S1518-87872018052000605.pdf
34. Souza LHR, Brandão JCS, Fernandes AKC, Cardoso BLC. Falls on elderly and associated risk factors. Rev Aten Saúde [Internet] 2017 [acesso em 18 fev. 2020];15(54):55-60. Disponível em: https://seer.uscs. edu.br/index.php/revista_ciencias_saude/article/ view/4804/pdf

35. Moraes SA, Soares WJS, Lustosa LP, Bilton TL, Ferrioli E, Perracini MR. Characteristics of falls in elderly persons residing in the community: a population-based study. Rev Bras Geriatr Gerontol [Internet]. 2017 [acesso em 18 fev. 2020];20(5):691701. Disponível em: http://www.scielo.br/pdf/rbgg/ v20n5/1809-9823-rbgg-20-05-00691.pdf 